\title{
Communication Abilities of Non-Standard Language Speaking Children: A Follow-up Study
}

\author{
Erna Alant, D. Phil (Pretoria) \\ Department of Speech Therapy and Audiology, \\ University of Pretoria
}

ABSTRACT

There has recently been a growing awareness among speech and language pathologists about the problems of the non-standard language speaker when entering the school situation where standard language is predominantly used. This study deals with the preschool nonstandard language speaker and aims to investigate whether and to what extent the children's language and interaction patterns change after one year's exposure to a formal school situation. Results indicate that although certain language skills do change, the functional interactions patterns of these children tends to remain the same. These findings are interpreted within a social context and implications for intervention discussed.

\section{OPSOMMING}

Daar is 'n groeiende bewuswording binne die geledere van die spraak-en taalterapeute oor die probleme rakende die nie-standaardtaalspreker, veral wanneer die nie-standaardtaalsprekende kind die skoolsituasie betree waar standaardtaal hoofsaaklik gebruik word. Hierdie studie handel oor die voorskoolse nie-standaardtaalspreker en poog om na te vors of, en in welke mate, die kinders se taal en interaksiepatroon verander na een jaar se blootstelling aan 'n formele skoolsituasie. Resultate dui daarop dat hoewel sekere taalvaardighede verander het, die funksionele interaksie patroon van die kinders neig om meer konstant te bly. Hierdie bevindings word geïterpreteer binne ' $n$ sosiale konteks en implikasies vir intervensie word bespreek.

In the recent literature on language evaluation, much emphasis has been placed on the assessment of functional language, particularly in relation to non-standard language speakers. This pragmatic approach reflects an awareness of the difficulties involved in comparing and describing communication abilities of children merely by looking at the formal structure of language (Labov 1972, Trudgill 1983, Erickson and Omark 1981). The inappropriateness of labelling the use of non-standard language structures as 'pathological or deviant' due to inflexibility in the application of syntactic, phonological or other language rules, has contributed to an increasing consciousness of the equality of language variations as potential codes for the transmission of various kinds of messages (Davis 1985, Sturm 1984, Edwards 1979, Labov 1972!.

This acceptance of the equality of language variations (Davis 1985), does not deny the existence of a standard language in society as represented by reading and writing. It acknowledges that societies need standard languages in order to function effectively, just as "schools have to accept and teach standard language if only because one of the primary purposes of education is literacy" (Davis 1985: 191).

The consequence of schools aiming at familiarizing children with standard language as required for reading and writing, is the frequent existence of a 'mismatch' or 'discontinuity' between the language children use at home and at school (Labov 1972, Trudgill 1983, Cox and Jones 1983, Adler 1979).
"... some children have little or no experience of the interactional demands of the school because of the type of conversational interaction which they have experienced at home, and so they are less able to cope with classroom talk" (McTear 1985:21).

The nature of the discontinuity between home and school language is, however, not clear and could include a complex combination of social and linguistic aspects ranging from the use of different language structures to different communication styles (Farran 1982). The question arises as to what extent children's language proficiency can change in coping with the more formal school situation after exposure to the educational system. It would be interesting to determine whether the language abilities and communication styles of children can be modified effectively in order to facilitate interaction at school after some experience with formal schooling.

Most of the longitudinal research on the language abilities of children exposed to schooling has been done by the American Headstart Programmes (Moore 1979, Kellaghan 1977), as well as the projects on the Educational Priority Areas (EPA) in Britain (Cox and Jones 1983). These studies indicate that children who were part of these projects enjoyed only temporary advantages in adapting to the formal school situation and that they gradually drifted back towards the performance level of their companions who had no exposure to preschool education (Moore 1979). Explanations for these findings varied from ineffectively or poorly directed pro- 
grammes (Kellaghan 1977), to the acceptance that language is part of a social structure and, therefore, that exposure to some hours of language or educational stimulation does not effectively change the interaction style of the individual (Sturm 1984).

The measurement of effective participation in a school context is, however, problematic in view of the difficulties involved in developing relevant communication parameters for indicating learning performance. School achievement gives some indication of children's ability to cope with scholastic demands, although only the results or outcome of learning behaviour is reflected. The process of learning itself is not considered in this kind of evaluation.

In this respect it is pertinent to differentiate between "basic communication proficiency" which refers to interpersonal communicative skills and "cognitive academic language proficiency" which refers to the understanding and ability to manipulate meanings inherent in the language itself as proposed by Cummins (1981) and discussed by Skinner [1985]. Alhough these skills are interrelated, the nature of language proficiency required in different contexts varies in relation in the degree of context-dependency as well as cognitive demands (Skinner 1985). Different communication skills can therefore be identified in the formal learning situation, including interactive skills and the more cognitively orientated academic language skills.

Depending on the general approach to teaching, a more interactive (less authoritarian) or on the other hand, a representative interaction style (frequently associated with a more formal, authoritarian academic situation], could dominate. An interactive model of learning emphasizes the ability of the child to participate in the teaching situation by using a variety of language functions, i.e., to initiate, to respond, or to ask for clarification. Interaction takes place primarily between pupil and teacher (Coulthard 1977, Britton 1973). Formal instruction, however, also involves at least to some extent the ability to listen to relatively long and cognitively demanding verbal instructions or explanations in order to respond appropriately in the context, i.e., representational skills as defined by Russel and Russel (1979). Different communication styles can therefore be identified in the teaching situation and should be noted when evaluating the communication abilities of children in the school situation (Alant 1984).

It is against this background that the present study sets out to investigate children's communication performance in two contexts: a more cognitively demanding representative context in which comprehension questions relating to a story are asked similar to the question-answer situation at school, and a less cognitively demanding conversational context where children and an adult simulate communication skills required in interaction with the teacher in the classroom. In view of this approach two questions demand to be posed, namely whether and to what extent the communication skills of children on a preschool level have changed after one year of exposure to the formal school situation and secondly, whether there is any significant association between overall school performance and communication ability as defined in the two contexts.

\section{METHODOLOGY}

Seventy-seven Afrikaans-speaking children were tested on a preschool level. All of these were prospective schoolbeginners in the following year at a specific school in Eersterust. The whole population of children that could be located was included in the study. Twelve months later the same children, were retested at the end of their first school year. Only forty-one of the original sample could be located at the school and were therefore included in the study. All the children tested were from the Nantes area which is one of the poorer areas in Eersterust, a community on the periphe. ry of Pretoria. It should be noted that, although close to the city, this township is relatively isolated from the larger Afrikaans-speaking community in Pretoria, and this has been contributed to the development of certain linguistic differences between the two Afrikaans-speaking communities. These linguistic variations include differences in vocabulary, syntactic structures as well as pronunciation (Claassen and Van Rensburg 1983).

The average gross household income of people in Eersterust was determined by a survey in 1979 (Lotter, Strijdom and Schurink 1979) and reported to be less than R300 a month per sub-economical four-roomed house. As most of the housing in the Nantes area is sub-economical, this could be taken as a reflection of the average income of this subdivision of the township. The average number of dependents per household was at least eleven (Lotter et al. 1979:19).

Table 1 gives a brief description of the subjects used in the study. As the same children were tested on both occasions, only the relevant information will be given at the point of the second testing.

Table 1: Description of subjects at the end of their first school year

\begin{tabular}{|l|l|}
\hline Variable & Description \\
Number of children & 41 \\
Male/female distribution & $48,8 \%$ female; $51,2 \%$ male \\
Mean age & 6,96 (SD =0,53) \\
Scholastic achievement at the & $65 \%$ pass, 35\% fail \\
end of the first year & \\
\hline
\end{tabular}

\section{MATERIALS}

The Story:

All children were exposed to a story and were required to answer questions about it. The same story and questions were used on both testing occasions.

Although the effect of exposure to the story during the first testing could have influenced performance on the task in the second testing, this influence was considered minimal. Firstly, there was a twelve month break between the two testings, which generally is regarded as a sufficient period for retesting (Dunn and Dunn 1981). Secondly, no answers were given to the children during the first testing șituation, therefore no feedback was provided in terms of the correct answers.

The story 'The fox and the crab' was adapted from Berry (1969) as modified by Alant (1984) for use with five-and-ahalf year olds in a comprehension situation (see Appendix 1). The story was lengthened for the purpose of testing com- 
prehension by including more characters (factual material) while maintaining the basic story together with the inferences required to complete the ending. The story was told on video-tape /with facial clues and gestures only, in order to stimulate stories or narratives occurring in normal communication). A nursery school teacher as well as the teachers of the beginning classes at the school were asked to view the tape and to evaluate its appropriateness with regard to middle class biases in vocabulary, cultural prejudice, content, and age appropriateness.

Some minor changes were suggested after which the story was recorded for use in the pilot and main study.

\section{Conversational themes:}

The conversational themes, were developed from the pilot study undertaken before the first testing. These topics centered around the children's interests and activities at school and at home, e.g., the family and favourite television programmes.

\section{PROCEDURE:}

Each child was tested individually at school in a classroom specially equipped for the testing of children. During the first phase of the testing the children were required to observe the video-story ( 4 minutes) after which the comprehension questions were put to them. Immediately after this interaction, the therapist having watched the video with the child, proceeded to initiate a conversation ( 12 minutes). The reason for this specific procedural sequence is that observation of the television story was considered to be less threatening to the children at the beginning of the interaction. The same therapist interacted with the children on both occasions in order to control for idiosyncratic communication differences. The complete contact with the child was recorded on video-tape for analysis at a later stage. However, the influence that the presence of the video equipment might have had on the performance of the children has to be considered. Similarly the presence of a standard language speaker as a conversationalist could have had an inhibiting influence on the children. These two, factors were held constant during both testings in order to compare the children's behaviour in the same situation under similar circumstances one year later.

\section{Verbal analysis:}

Story situation:

Accuracy of answers: Four questions were asked, based on the story (Appendix 1). These questions were ranked from easy to difficult, that is, from questions demanding immediate reproduction of facts to questions relating to answers based on inferences drawn from the story. The grading of the questions was first tested by Alant (1984) and proved to be satisfactory. The specific sequence of questions was deemed important as easy questions could be a motivating factor in the beginning of an interaction.

\section{Probing:}

Probing was used in order to prevent inhibited children from being discredited for lack of understanding. Although the effectiveness of probing can be questioned, particularly with this sample of children (Faegans and Farran 1982, Labov 1972), probes could contribute to an increase of verbal behaviour (Stalnaker and Creaghead 1982; Warren, McQuarter and Rogers-Warren 1984|. A probe was defined as a verbalization from the therapist followed by a pause (approximately one second) during which the child could be given an opportunity to respond. Probing was used when children did not respond or when they responded with "don't know" or other short replies. Non-directive probing was used at first, followed by more direct probes depending on the vagueness of the answers.

Functional analysis of conversation:

The functional categories developed by Dore $\{1977\}$ were adapted for use in the analysis of conversation between the therapist (adult) and child (Appendix 2). This analysis only describes the kinds of utterances used in the interaction (structural-functional) whereas the transactional aspects inherent in the semantic development of the conversation were not taken into account (McTear 1985).

All the interviews were transcribed for use in the functional analysis. Audio-recordings were used in order to enable the analyzers to do the functional analysis with the written as well as the audio-information. The inclusion of both transcript and audio-material in the analysis was necessary in order to facilitate reliable judgements of utterances, particularly in view of the fact that the function of an utterance cannot necessarily be deduced from the structure of the utterance (Willes 1981).

Two groups of two analyzers each worked together so as to control their interpretations of the functional categories in order to increase reliability of the rating. An average of $96 \%$ agreement between raters was calculated for each interaction.

\section{SCHOLASTIC ACHIEVEMENT:}

An overall indicator of the children's academic achievement was obtained from the class teachers in the form of their final class mark. This mark constituted the average performance of the child on all the different levels, i.e., reading, writing, comprehension test, oral language and arithmetic. Although it could be argued that scholastic achievement as defined above is too broad for comparison with the above testing procedure, language can be seen as an important, although not necessarily the only, factor influencing performance on all these levels. Due to the complexity of factors that could influence school performance le.g., visual problems) present findings should therefore only be interpreted tentatively.

\section{STATISTICAL ANALYSIS:}

Descriptive measures such as means, standard deviations and standard error of the means were calculated to describe the performance of both groups on different variables. The means of specific variables were used so that certain features of the groups could be represented graphically. The 
U-test of Wilcoxon Mann-Whitney was used to test for differences in population means.

\section{RESULTS}

The results will be discussed in three broad categories:

- The children's performance on the comprehension story;

- The functional analysis of communication over the two testings;

- The relationship between scholastic achievement and communication performance on the last testing fi.e., after the children had had eleven months' exposure to formal schooling).

\section{The children's performance on the comprehension story}

Table 2 shows differences in the means of the children's performance on the different variables between the first (preschool) and second (school-going) testing.
Table 2: Test for difference in means with respect to accuracy of response and probing needed to elicit responses

\begin{tabular}{|l|l|c|l|}
\hline & Variable & T-value & Probability \\
\hline \multirow{2}{*}{ Accuracy } & Question 1 & 1,27 & 0,2098 \\
& Question 2 & 4,74 & $0,0001^{* *}$ \\
& Question 3 & 2,87 & $0,0065^{* *}$ \\
& Question 4 & 2,88 & $0,0064^{* *}$ \\
\hline TOTAL & & 4,91 & $0,0001^{* *}$ \\
\hline Probing & Question 1 & 0,64 & 0,5253 \\
& Question 2 & 2,24 & $0,0305^{*}$ \\
& Question 3 & $-0,83$ & 0,4119 \\
& Question 4 & 1,18 & 0,2433 \\
\hline TOTAL & & 1,99 & 0,0537 \\
\hline
\end{tabular}

** $=$ Significant on $1 \%$ level, ${ }^{*}=$ Significant on $5 \%$ level.

The above table indicates that there are significant differences between the means of most of the questions with respect to the accuracy of the responses, whereas there are relatively few significant differences on the amount of probing necessary to elicit responses from the children.

\section{Functional analysis of conversation}

Figures 1 and 2 graphically represent the mean number of utterances within each category for each testing.

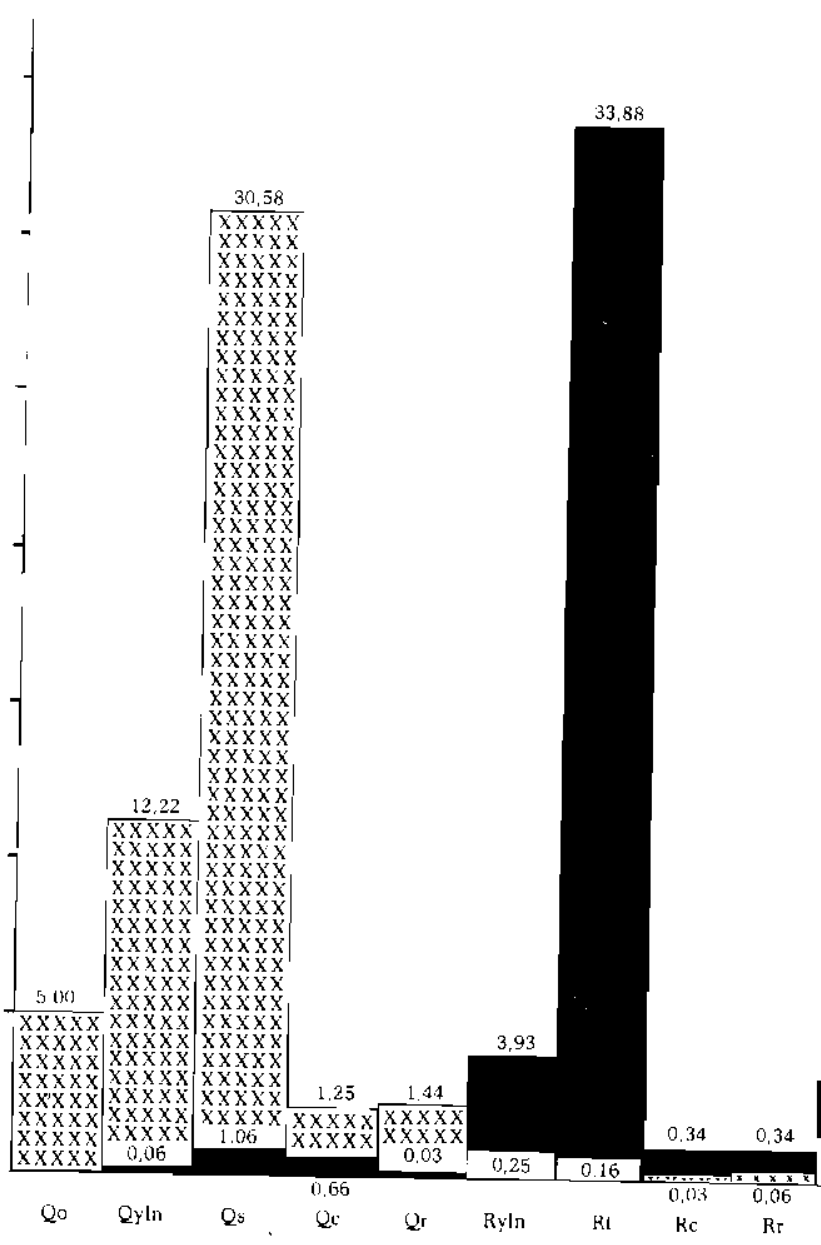

Figure 1: Functional analysis of conversations between therapist and child in 1984

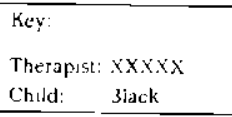

Qo = Open question

Qyln = Yesino question

Qs = Specifie question

Qc = Questonn for ciarification

Qh = Question repealed

Rỵlu $=Y$ :sino response

RF = Factual respons:;

Rc = Clarifying response

Rr = Repeatung response

- Descriplion

$=$ Statement

- Acknowledgement. acceptaice

- Acknowledgement: positive

= Acknowledgement: negative

= Organization device: attention

= Organization device: politeness

= Organizatıon device: contact

= Performatives

$=$ Interuptions

- Ir:ulevant utterances 


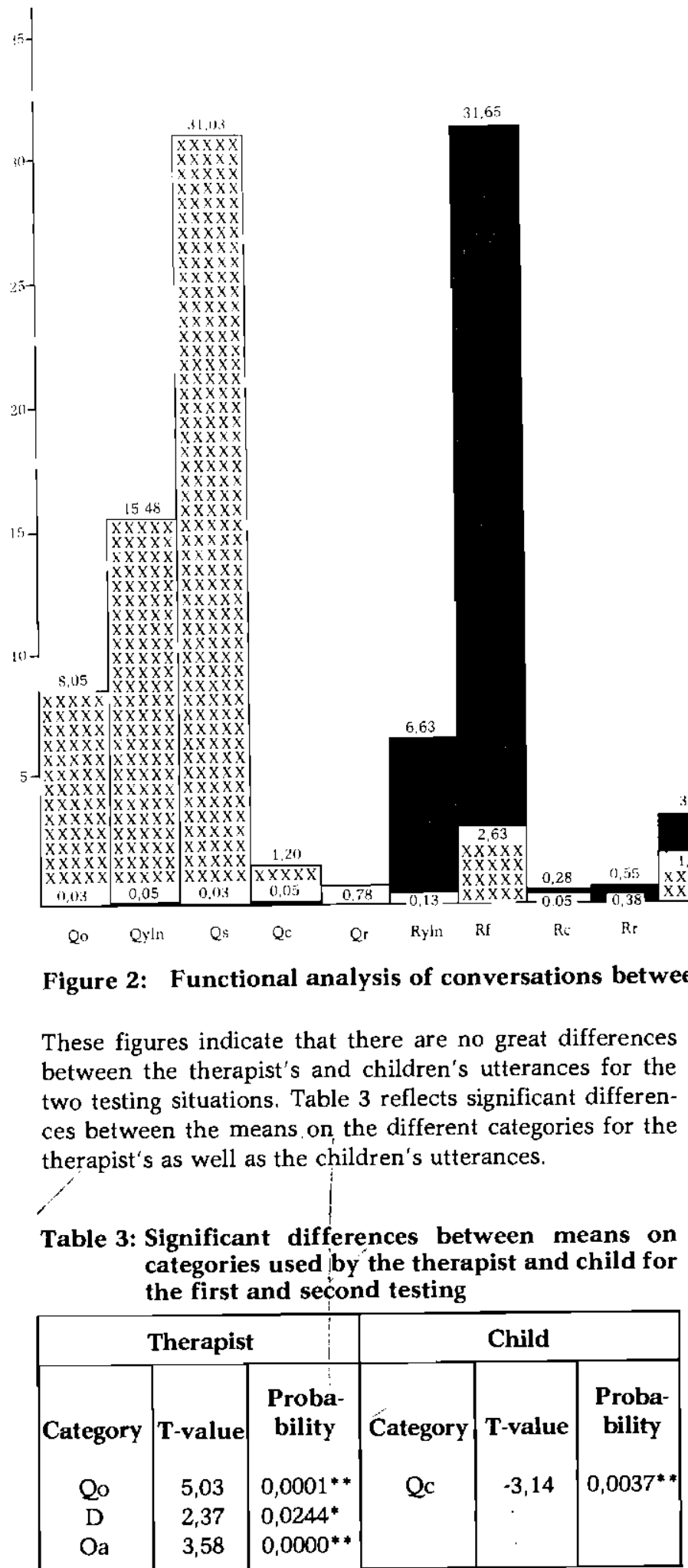

Clarification of abbreviations in Appendix II .

** = Significant on $1 \%$ level, ${ }^{*}=$ Significant on $5 \%$ level.

Correlation between overall scholastic achievement and communication parameters

Tables 4 and 5 represent the differences between the means of the story and conversational variables of two groups of children, group 1 representing the children who passed the first year of schooling $(65 \%$ in total $)$ and group 2 representing those who failed (35\% in total).
Table 4: Test for the difference in means between the two groups (children that failed and passed) with respect to the story variables

\begin{tabular}{|c|c|c|c|}
\hline & Variable & T-value & Probability \\
\hline \multirow[t]{4}{*}{ Accuracy } & Question 1 & \multicolumn{2}{|c|}{$\begin{array}{c}\text { (Values were the same for } \\
\text { one class level) }\end{array}$} \\
\hline & Question 2 & $-0,52$ & 0,6065 \\
\hline & Question 3 & $-1,37$ & 0,1778 \\
\hline & Question 4 & $-2,21$ & $0,0336^{*}$ \\
\hline TOTAL & & $-2,20$ & $0,0038^{*}$ \\
\hline \multirow[t]{4}{*}{ Probing } & Question 1 & 2,25 & $0,0326^{* *}$ \\
\hline & Question 2 & 1,27 & 0,2136 \\
\hline & Question 3 & 2,65 & $0,0120^{*}$ \\
\hline & Question 4 & 1,27 & 0,2124 \\
\hline TOTAL & & 2,41 & $0,0210^{*}$ \\
\hline
\end{tabular}

** = Significant on $1 \%$ level, * = Significant on $5 \%$ level.

From Tables 4 and $\mathbf{5}$ it is clear that there are some differences between these two groups on the story variables, although fewer significant differences seem to be indicated between the first and second testing on the functional use of language. 
Table 5: Significant differences in means with respect to the functional categories used by the therapist and child

\begin{tabular}{|c|c|c|c|c|c|}
\hline \multicolumn{3}{|c|}{ Therapist } & \multicolumn{3}{c|}{ Child } \\
\hline & & $\begin{array}{c}\text { Proba- } \\
\text { bility }\end{array}$ & Category & T-value & $\begin{array}{c}\text { Proba- } \\
\text { bility }\end{array}$ \\
$\mathrm{Qr}$ & 2,55 & $0,02^{*}$ & $\mathrm{Ry}$ & $-1,94$ & $0,05^{*}$ \\
$\mathrm{Aa}$ & 2,84 & $0,01^{* *}$ & & & \\
\hline
\end{tabular}

Clarification of abbreviations in Appendix II

** = Significant on $1 \%$ level, ${ }^{*}=$ Significant on $5 \%$ level.

\section{DISCUSSION OF RESULTS}

Children's performance on the comprehension story:

Accuracy of the responses:

There is a highly significant difference in the children's accuracy of response between the first and second testing, reflecting definite growth in semantic understanding of the story during the twelve months. This improvement in the children's comprehension behaviour is reflected in questions two to four, with question one not showing any significant difference. This absence of a significant difference on question one can be expected in view of the inherent nature of the question as it simply demands the name of the animal which is the main character of the story.

The highly significant difference between the means on question two is, however, interesting considering the demands made on memory and recall of the children as they were required to name all the animals that the fox met. This finding is in agreement with developmental research reporting increased ability to remember factual detail as age increases (Bloom and Lahey 1978).

Question three indicates the ability to analyse the purpose of the actions in the story by describing the plan that the fox had. The significant improvement in answers on this question is in congruence with the research done by Peterson and McCabe (1983) where they emphasize the older child's tendency to move away from describing action sequences to expressing relationships (cause - effect or intentionality) between actions. They explain this phenomenon in terms of the children's increase in control over their environment in that they become better able to participate in events whereas the purpose of these events might not have been evident to them before.

Question four emphasizes the ability to constructively process information by demanding that the children make inferences from the story. The present data confirm normal developmental research reporting an age effect in the constructive processing of information (Small and Butterworth 1981, Paris, Lindauer and Cox 1977). Weissmer (1983) also reported fewer inferences from children aged 5,5-6,7 compared to those aged $7,7-9,2$.

In general the language performance of these children indicates an increased ability to cope with the two main language proficiency vectors as formulated by Cummins (1981), i.e., the ability to determine and communicate mean- ing in the absence of contextual clues and the ability to think in more 'cognitively demanding' situations. Although this improved performance could also be interpreted as the result of the children's familiarity with the testing situation, it is doubtful whether this is the case particularly in view of the twelve month gap between testings.

\section{Probing necessary to elicit responses:}

Only question two indicates a significant difference (at the $5 \%$ level] between the means of the two testings, implying that more probing was done on the second than on the first testing. This finding is contrary to what is expected as it implies that the children needed more encouragement to answer the questions on the second testing. This finding raises questions as to the influence of probing on the accuracy scores of the children. The association between probing and accuracy for this particular procedure has, however, been computed, and indicates a highly significant negi ${ }^{+}{ }^{+}$ve correlation [ $1 \%$ level) between the two variables. As probir., increased, the accuracy of the responses, in fact, decreased, which means that the present finding points to improved listening and memory-recall abilities of the children rather than improved accuracy due to an increase in probing. A second important implication of this finding is that the children were less at ease in coping with the question. answer situation at the time of the second testing. The asymmetric nature of the interaction has thus not shown any decline; rather the children might have become more conscious (as indicated by question 2) of the inherent inequality in the adult-child interaction as discussed by French and Woll (1981) and Romaine (1984). This increase in awareness could be indicative of an authoritarian teacher-pupil relationship.

\section{Functional analysis of conversation:}

From Figures 1 and 2, it is clear that the pattern of functional categories for the two testings stayed virtually the same, i.e., a high frequency of questions from the therapist, while the child mostly responded. This information confirms the notion that the same interaction (e.g., adult-child) tends to elicit similar functional behaviour (Gallagher and Prutting 1983). The children showed little initiative (little additional information was given, for example few descriptions (D), stories (S) or questions (Q) were forthcoming) which could also be a reflection of the asymmetric nature of the interaction (Romaine 1984).

The test for the difference between the means for all the categories, indicate that the therapist used significantly more open-ended questions $\mid \mathrm{Q}$ | $\}$, descriptions $\{\mathrm{D} \mid$ and organizational devices $(\mathrm{Oa})$ to attract the child's attention, and encourage interactions during the second testing. The child, however, did not experience the interaction any differently from the first in that there was no notable increase in the child's initiation, descriptions or statements. Romaine (1984:22) describes this phenomenon as follows:

"Distribution of power is clearly delimited and free conversation is not expected. Attempts to elicit narratives and spontaneous speech by breaking out of the question/answer format violate the norms governing the event. According to Wolfson, the ir.formant's reaction to this may be surprise, confusion, suspicion or even resentment". 
The lack of response from the children could, however, also indicate an inability to adapt to the dynamics of the conversation due to either insensitivity or insecurity on their part (McTear 1985). Unfamiliarity with the prevalent conversational rules could thus have contributed to the seeming lack of response from the children (Willes 1981).

The finding indicating a significant decrease in the children's questions for clarification during the second testing is interesting, in view of the fact that this behaviour could indicate a lesser need to ask for clarification due to improved comprehension. As there were no significant differences in the other functional categories of the children, it is difficult to verify this interpretation. A more likely interpretation could be that the children were more inhibited as they had become more conscious of the asymmetric nature of the relationship.

\section{Scholastic performance of the children:}

After having described the performance of the children in both testings, it is important to get some measure of the effectiveness of the children's performance at school, in order to understand the prerequisites for learning within the school context.

Although the children who failed and those who passed at the end of their first school year differed significantly in their performance on isolated questions in the story, the total accuracy as well as the total probing score indicate significant differences on a $5 \%$ level. The children who passed therefore obtained significantly better accuracy scores on the total performance and they also needed less probing on the four questions in order to respond. One could therefore conclude that these children seemed to cope better with the situation demanding more cognitive academic language proficiency (Cummins 1981).

As far as the functional categories are concerned, there is only one significant difference between the two groups' functional language categories, while there are two significant differences on the categories used by the therapist with the two groups.

The significant difference in the frequency of yes/no responses between the two groups of children is most interesting, particularly as the academic achievers tended to use more yes/no replies. Traditionally a high premium was placed on the syntactic completeness of utterances, and restricted verbalization was frequently equated with limited language abilities (Bernstein 1973, Lee, Koenigsknecht and Mulhern 1975, Crystal, Fletcher and Garman 1977). New theoretical insights, however, stress that structural completeness is no prerequisite for effective communication (Labov 1972). The higher frequency of yes/no responses in this study could therefore rather be related to better understanding on the part of the children and an inability to express themselves more explicitly.

As for the changes occurring in the therapist's utterances when talking to children of different academic achievement, it is notable that she had to repeat her own questions (Qr) more often to the children who were academically poorer, whereas she also accepted more of their verbalizations (Aa), possibly in an attempt to encourage further verbalization. She therefore tried to compensate for the child's apparent difficulties in the situation by accepting a greater variety of utterances.

It should be underlined in conclusion, that the present study aims at describing children's communication behaviour in two contexts by using certain methodological and analytical procedures. Data can, therefore, only be interpreted within the context of the study. It is no intent of the author to generalize the present findings to other language skills or communication situations.

In terms of the theory of discontinuity, it could be argued that the children who had failed their first year of schooling had difficulty in orientating themselves to the situations demanding more cognitive academic language proficiency. This problem in orientation could be due to many factors, including cognition (which could according to Selowsky (1980) also be related to malnutrition), difficulty in coping with the standard language as required in the more formal story situation, as well as a delay in the development of meta-linguistic abilities needed for the making of inferences in a given situation (Wallach and Butler 1984).

As far as functional language is concerned, no big differences in the children's performances were noted between preschool- and one year of schooling-level, indicating that the children's conversational abilities as defined by these categories did not show a significant change or improvement. Due to the minimal differences found between the skills of the children who had failed and those who had passed academically, it can also be said that conversation skills as defined in this study did not influence learning performance in the school. The model adhered to in the classroom therefore seems to be of an authoritarian nature (Britton 1973) which demands little initiative and active participation on the part of the children. In the same way the interaction model prevalent in the children's daily life could also be of a more authoritarian nature, as is suggested by Romaine (1984).

The question arises as to the relevance of trying to change or improve conversational abilities within the context of an authoritarian teaching model and possibly also a parent or adult dominated society. This is a difficult and complex question to answer. The problem remains, however, as to how these children will be able to cope with a different level of academic achievement, where an interactive approach to learning is more prominent, for example, at secondary school or university. In the case of these children, they are all from the same geographical area and therefore isolated from contact with children from other areas. Although this aspect facilitates adaptation of the children to the school situation, it could also be considered as a very protective learning environment, which has the disadvantage that, once confronted with the broader society, the children might experience more difficulties due to the 'mismatch' between educational and communication strategies in the different contexts. There is, however, no merit in regarding the problem of different interaction styles /which reflect different ways of life according to Labov 1972 and Luckmann 1975 ) in isolation from the social situation in which they occur. Intervention strategies should therefore only be initiated after extensive contact and collaboration with the communities involved, in order to prevent a different communication style from being mistaken for a pathological interaction model in the context. 
The implications of these findings for language assessment and remediation are multiple. Firstly, it is important to realize that there is no objectively defined concept of pathology. Deviancy is defined within a particular context, which implies that there is no 'ideal' communication model within which therapists remediate. Therapy should be directed at meeting the needs of the patient which presupposes an understanding of the environment and context within which the individual lives. The general interactive style of the school context as well as the environment has to be considered before deciding that functional behaviour is inappropriate or limited.

Secondly, the range of language skills tested should be closely considered, particularly when working with school-going children. The evaluation of functional communication skills does not necessarily reflect the child's cognitive academic language proficiency as indicated by the poor correlation between school performance and functional communication illustrated in this study.

Finally, it is clear that when preparing children for formal learning within a context as described here, it is important to focus on cognitive academic language proficiency in order to facilitate the transition from home to school environments.

\section{ACKNOWLEDGEMENTS}

This research is part of the 'Eersterust Project' of the Department of Speech Pathology and Audiology of the University of Pretoria. I would like to express my sincere appreciation for the invaluable contributions of all the team members: Annemarie Beukes, Heila van den Berg, Alta Kritzinger, Ingrid van Zyl, Rialette Gous, Santie Meyer, Marina Hurter and Felicity van Rensburg. The assistance of Mrs. M. Botha as well as Prof S.H.C. du Toit in the computerisation and statistical analyses of the data is also greatly appreciated. Finally, the dedicated participation of the teachers and children at the school contributed greatly to the success of the project.

\section{REFERENCES}

Adler, S. Poverty Children and Their Language New York: Grune \& Stratton, 1979.

Alant, E. The Development of a Procedure for Aralysing Communication of Preschool Children. D.Phil. Thesis, University of Pretoria, 1984 |unpublished].

Bernstein, B. (Ed.) Class, Codes and Control. London: Routledge and Kegan Paul, 1973.

Berry, M. Language Disorders of Children. Englewood-Cliffs: Prentice-Hall, 1969

Bloom, L. \& Lahey, M. Language Development and Language Disorders. New York: John Wiley, 1978.

Britton, J. Language and Learning. London: Penguin Books, 1973.

Claassen, G. and Van Rensburg, M.C.J. Taalverskeidenheid. Cape Town: Academica, 1983.

Coulthard, M. An Introduction to Discourse Analysis. London: Longman, 1977

Cox, T and Jones, G. Disadvantaged Eleven Year Olds. Oxford: Pergamon Press, 1983.

Crystal, D. and Fletcher, P. and Garman, M. The Grammatical Analysis of Language Disability. London: Edward Arnold, 1977

Cummins, J. The Role of Primary Language Development in Promoting Educational Success for Language Minority Students. In California State Department of Education (Eds.) Schooling and Language Minority Students. Los Angeles: Evaluation, Dissemination and Assessment Center, 1981.

Davis, A. Standard and Dialect English. Journal of Multilingual and Multicultural Development, 6, 2, 183-192, 1985.

Dore, J. On Them Sheriff: A Pragmatic Analysis of Children's Responses. In S. Ervin-Tripp and C. Mitchell-Kernan (Eds.) Child Discourse, New York: Academic Press, 1977.
Dunn, L.M. and Dunn, L. Peabody Picture Vocabulary Testrevised. American Guidance Service. Minnesota: Circle Pines, 1981.

Edwards, J.R. Language and Disadvantage. London: Edward Arnold, 1979.

Erickson, J.G. and Omark, D.R. Communication Assessment of the Bilingual, Bicultural Child. Baltimore: University Park Press, 1981.

Faegans, L. and Farran, D.C. The Language of Children Reared in Poverty. New York: Academic Press, 1982.

Farran, D.C. Intervention for Poverty Children: Alternative Approaches. In L. Faegans and D. Farran (Eds.) The Language of Children Reared in Poverty. New York: Academic Press, 1982.

Francis, $\mathrm{H}$. What Does the Child Mean? Child Language, 6, 227-241, 1978.

French, H. and Woll, B. Contest, Meaning and Strategy in Parentchild Conversation. In G. Wells (Ed.) Learning Through Interaction, New York: Cambridge, 1981.

Gallagher, T. and Prutting, C. (Eds.) Pragmatic Assessment and Intervention Issues in Language. California: College-Hill Press, 1983.

Kellaghan, T. The Evaluation of An Intervention Programme for Disadvantaged Children. Windsor: NFER Publishing Company 1977.

Labov, W. The Logic of Non-Standard English. In Giglioli, P $\mid \mathbf{E d}\}$. Language and Social Context, New York: Penguin, 1972.

Lee, L.L.; Koenigsknecht, R.L. and Mulhern, S. Interactive Language Development Teaching. Evanston: Northwestern University Press, 1975.

Lotter, J.M.; Strydom, H.G. and Schurink, W.J. Eersterust: 'n Sosiologiese Studie van 'n Kleurlinggemeenskap. Pretoria: RGN 1979.

Luckmann, T. Sociology of Language. Indianopolis: The BobbsMerrill Company, 1975.

McTear, M. Children's Conversation. Oxford: Basil Blackwell, 1985.

Moore, S. Past Research and Current Perspectives on Head Start and Follow Through. Viewpoints in Teaching and Learning, $55,3,75-82,1979$.

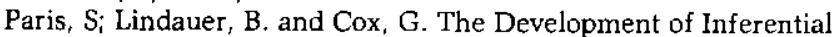
Comprehension. Child Development, 48, 1728-1733, 1977.

Peterson, C. and McCabe, A. Developmental Psycholinquistics: Three Ways of Looking at a Child's Narrative. New York: Plenum Press, 1983.

Russel, D. and Russel, E. Listening Aids Through The Grades. New York: Collumbia University, Teachers College, 1979.

Romaine, S. The Language of Children and Adolescents: The Acquisition of Communication Competence. Oxford: Basil Blackwell, 1984.

Selowsky, M. Preschool Age Investment in Human Capital. In J. Simmons (Ed.) The Education Dilemma: Policy Issues for Developing Countries in the 1980's, New York: Pergamon Press, 1978 .

Skinner, D. Access to Meaning: The Anatomy of the Language/ Learning Connection. Journal of Multilingual and Multicultural Development, 6, 2, 97-116, 1985.

Small, M. and Butterworth, J. Semantic Integration and the Development of Memory for Logical Inferences. Child Development, 52, 732-735, 1981.

Stalnaker, L.D. and Creaghead, N.A. An Examination of Language Samples Obtained under Three Experimental Conditions. Language Speech and Hearing Services in Schools, 13, 2, 12i128,1982 .

Sturm, J. Deficit and Difference: A False Dichotomy in an Educational Perspective. In K. Deprez (ed.), Sosiolinquistics in the Low Countries. Amsterdam: John Benjamins Publishing Company, 1984.

Trudgill, P. Accent, Dialect and the School. London: Edward Arnold, 1983.

Wallach, G.P. and Butler, K.G. Language Learning Disabilities in School-Age Children, London: Williams and Wilkins. 1984.

Warren, S.F.; McQuarter, R.J. and Rogers-Warren, A.K. The Effects of Mands and Models on the Speech of Unrespońsive Language Delayed Preschool Children. Joumal of Speech and Hearing Disorders, 49, 43-52, 1984.

Weissmer, S.E. Constructive Comprehension Abilities Exhibited by Language-Disordered Children. Journal of Speech and Hearing Research, 23, 2, 175-184, 1983.

Willes, M. Learning to Take Part in Classroom Interaction. In P French and M. Maclure (eds.). Adult-Child Conversation. London: Croom Helm, 1981. 


\section{APPENDIX 1}

STORY

\section{Unit 1}

\section{E. 3} E.3 E.2 E.3 Eendag// stap ou jakkals in die bos./ Hy loop en spog te lekker, / want hy kan tog SO: vinnig hardloop.// Toe hy nog so stap, sien hy vir olifant onder die boom staan.// "Goeie Môre OU olifant" sê jakkals./ "Kom ons hardloop reisies, dan kyk O:NS wie van ons twee hardloop die vinnigste. "// Ou olifant dink toe so 'n bietjie en sê toe "Agge nee ou jakkals jy is gans te vinnig vir MY."/ Ou jakkals lag te lekker./ "Ja ou olifant, ek sal jou sommer vê:r wen."'// En so stap jakkals toe aan.//

\section{Unit 2}

Toe jakkals nog so stap./ sien hy vir skilpad./ "Goeie Môre skilpad./ Kom ons hardloop reisies dan kyk ons wie van ons twee is die vinnigste."/ Skilpad dink toe so 'n bietjie/ en sê: "Agge nee ou jakkals jy is gans te vinnig vir My."// Ou jakkals lag te lekker. Dis tog te lekker vir hom om te weet dat al die diere te bang is om teen hom reisies te hardloop.// En so stap jakkals toe aan.../I

\section{Unit 3}

Toe jakkals nog so stap, sien hy vir krap op die grond./ "Goeie môre ou krap. Kom ons hardloop reisies, dan kyk ons wie van ons twee is die vinnigste."// Ou krap dink toe so 'n bietjie...// en toe kry hy 'n baie Goeie plan./ "Goed ou jakkals, kom ons hardloop reisies dank kyk ons wie van ons twee is die vinnigste."// Ou jakkals is stom geslaan./ Hy kan nie glo dat krap teen hom wil reisies hardloop nie.//

\section{Unit 4}

Die twee begin toe hardloop./ MAAR net toe jakkals begin hardloop, spring krap op jakkals se stert en Kl:ou daar vas./ Jakkals hardloop baie vinnig tot by die wenpaal./ En toe hy by die wenpaal kom/ skud hy sy stert en kyk om om te sien waar die krap is.// Huuu... en daar sien jakkals vir krap $O P$ DIE GROND! "Ag Ou jakkals," sê die krap toe "Ek wag al lankal hier vir jou op die grond."

\section{VERBAL ANALYSES:}

Accuracy:

Question 1: Who walked in the veld?

$4=$ Fox

$3=$ Description of animal, no name

2 = Wrong animal

$1=$ No response/did not understand

Question 2: Whom did he meet there?

$4=$ All three correct

$3=$ Two correct

$2=$ One correct

$1=$ None correct

Question 3: What was the clever plan of the crab?

4 = Indication of relationship between action and intention

3 = Repeat actions involved, e.g., jumped onto tail and clung onto it
2 = Partially correct repetition of actions, e.g., hanged on tail

$1=$ No response/Response out of context/Do not know

Question 4: Who do you think won the race and why?

The WHY part of the question is scored only:

4 = In context explanation, e.g., crab won because he made a clever plan

$3=$ In context, but concrete, e.g., crab, because he jumped on the fox's tail

2 = Vague, out of context, e.g., fox, because he is faster

$1=$ No response/Do not understand/Do not know

\section{PROBING ANALYSES:}

All the probes on each question were calculated and categorized according to the following scoring system:

$\begin{array}{ll}1=0-5 \text { probes } & 3=11-15 \text { probes } \\ 2=6-10 \text { probes } & 4=16-20 \text { probes } \\ \mathrm{S}=\text { Smile } & 1-4 \\ \mathrm{E}=\text { Eye widening } / & \\ \quad \text { Eye narrowing } & 1-4 \\ \mathrm{~F}=\text { Frowning } & 1-4 \\ \mathrm{HN}=\text { Head nod } & \\ \mathrm{HS}=\text { Head shake } & \\ \mathrm{IL}=\text { Illustration } & \\ \text { Italics }=\text { Emphasized }\end{array}$

CAPITAL LETTERS $=$ STRESSED with more LOUDNESS

SO: $=$ The last sound prolonged

$I=$ Pause (untimed duration shown by number of $/ /$ )

/ - Longer pause

\section{APPENDIX 2}

Functional categories used for the analysis of the conversations between therapist and child. Adapted from Dore (1977).

Requests/Questions:

Qo : Open question, e.g., tell me...

Qy/n : Yes no question, e.g., do you know this?

Qs : Specific question, e.g., what are you doing?

Qc : Question for clarification (related to previous utterance) e.g., what?)

Qr : Repetition of previous question

Responses:

Ry/n : Yes/no response

Rf : Factual response to the question

Rc : Response on request for clarification

$\mathrm{Rr} \quad$ : Repetition of previous response

Descriptions:

D : Giving of additional information, descriptions 
Statements:

S : Statements not directly related to the previous utterance

Acknowledgements (non-requests):

$\begin{array}{ll}\text { Aa } & \text { : Accepting an utterance, e.g., hmm... } \\ \text { Ap : Positive acknowledgement, e.g., that was good } \\ \text { An : Negative acknowledgement, e.g., no, try again }\end{array}$

Organizational devices:

Oa : Utterance to draw attention, e.g., Justin, look here...

Op : Utterance indicating politeness, e.g., thank you

Oc : Utterance to maintain contact, e.g., Mmmm and then...
Performatives: Utterances aimed at changing behaviour

$\mathrm{P}$ : Utterances aimed at changing behaviour, e.g., don't do that, no, what are you doing?

Additional categories used:

Int : Interruptions

Irr : Irrelevant utterances

These two categories were indicated by putting the specific category in brackets e.g.

$\begin{array}{lll}\mathrm{T} & : \text { Waar werk jou pa? } & \mathrm{Qs} \\ \mathrm{K} & : \text { Saam met sy tjomme } & \text { (Rf) } \\ \mathrm{T} & : \text { Ja, en waar werk jou pa? } & \text { Aa...Qr } \\ \mathrm{K} & : \text { Daar by die swembad } & \mathrm{Rf}\end{array}$

C/O Jan Smuts and Gordon Aves Blairgowrie Randburg 2194

P.O. Box 84518

Greenside 2034

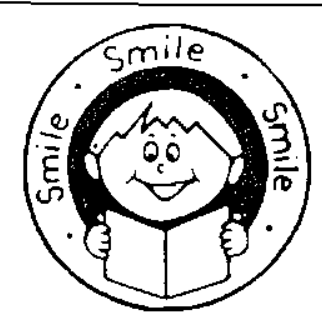

(011) 787-5810 $886-3843$

\section{Smile Education Systems (Pty) Ltd.}

We all know about the Smile Phonic Workbooks R2,99 each.

We all know about "Leergenot Fonemiese Werkboeke" R2,99 each.

We've all enjoyed Smile and Learn Book I.

But perhaps you don't know about

Peg-A-Pattern (A language based perceptual programme)

Learn to Think (Early leadership with logic)

Early Learning Animal Puzzles

At Smile Education Systems we know that language skills are important.

We encourage parents to communicate with their children.

We promote learning through perceptual and cognitive development.

Perhaps we can be of help to you. Pop in and see us or write to Smile Education Systems, P.O. Box 84518, Greenside 2034, for a free catalogue and price list. 